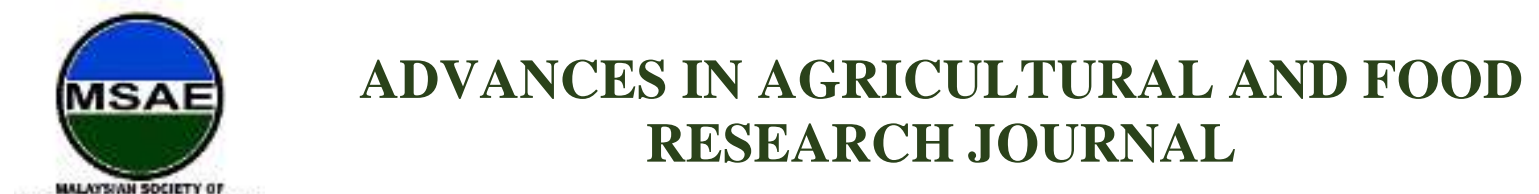

Original Research Article

\title{
Proximate Composition of Different Parts of White Cassava (Manihot esculenta Crantz) Plant as Ruminant Feed
}

Sarah Idris ${ }^{1}$, Rosnah Shamsudin ${ }^{1,2^{*}}$, Mohd Zuhair Mohd Nor ${ }^{2}$, Mohd Noriznan Mokhtar ${ }^{2}$, Siti Salwa Abd Gani $^{1}$ ${ }^{1}$ Halal Products Research Institute, Universiti Putra Malaysia, Serdang, Selangor, 43400, Malaysia, sarahidris85@gmail.com,rosnahs@upm.edu.my,ssalwaag@upm.edu.my

${ }^{2}$ Department of Process and Food Engineering, Faculty of Engineering, Universiti Putra Malaysia, Serdang, Selangor, 43400, Malaysia, rosnahs@upm.edu.my, zuhair@upm.edu.my, noriznan@upm.edu.my

*Corresponding author: Rosnah Shamsudin Department of Process and Food Engineering, Faculty of Engineering, Universiti Putra Malaysia, Serdang, Selangor, 43400, Malaysia; rosnahs@upm.edu.my

\begin{abstract}
Cassava (Manihot esculenta Crantz) is the third-largest carbohydrate food source in the tropical region after rice and corn. Its flesh is consumed as food and food products, while other parts of the plant are yet to be fully exploited. This research aimed to evaluate the proximate composition of the cassava plant (Rayong 90 variety). Six different parts namely leaf, petiole, young stem, tuber, cortex and periderm of white variety cassava plants were dried and powdered to determine their proximate composition (protein, carbohydrate, fat, crude fibre, ash and moisture content). The results showed that leaf provided the most nutrients compared to other parts. Leaf had $43.80 \%$ carbohydrate, $23.87 \%$ protein, $13.66 \%$ crude fibre, $6.53 \%$ ash, $6.00 \%$ crude fat and $5.00 \%$ moisture content. The crude protein for other parts was very low, ranging from $2.54 \%$ to $10.20 \%$. The white cassava variety plant was very high in carbohydrates, ranging from $30.48 \%$ to $86.77 \%$ of dry matter. The mean percentage of crude fat was within the range from $0 \%$ to $6.00 \%$. From the results, it can be concluded that the leaf of white cassava variety can be used to develop a high carbohydrate and protein ruminant feed as it has appreciable levels of nutrients.
\end{abstract}

Keywords: white cassava; leaf; proximate composition

Received: $13^{\text {th }}$ May 2020

Received in revised form: $20^{\text {th }}$ December 2020

Accepted: $30^{\text {th }}$ December 2020

Published: $4^{\text {th }}$ January 2021

Citation: Idris, S., Samsudin, R., Mohd Nor. M.Z., et al. (2021). Proximate composition of different parts of white cassava (Manihot esculenta Crantz) plant as ruminant feed. Adv Agri Food Res J 2021; $2(1)$ : a0000181. https://doi.org/10.36877/aafrj.a0000181

\section{Introduction}

Cassava (Manihot esculenta, Crantz) also known as tapioca is consumed across the world as one of the main sources of carbohydrates and also as a staple food (Alves, 2002). The ability of cassava plants to survive and grow on land even under poor soil, water supply and fertilizers allows an easier and cost-effective cultivation management of the cassava 
plants (Okudoh et al., 2014). In Malaysia, the total cassava growing area is around 2000 hectares, which in turn able to produce 35000 tonnes of fresh tubers (Department of Agriculture Malaysia, 2018). According to Malaysian Agricultural Research and Development Institute (MARDI), there are 80 varieties of the cassava plant that can be divided into two types, namely sweet and bitter cassava. Amongst the cassava varieties, the Rayong 90 variety is a bitter type due to its high content of cyanide (more than $100 \mathrm{mg} / \mathrm{kg}$ per fresh root). It is mainly used for animal feed or starch preparation (CIAT, 2009). High cyanide content in bitter varieties leads to its products processing and manufacturing at industrial scale (Boonseng et al., 1999) as most of the cassava varieties cultivated by farmers in Malaysia are the bitter type.

The average yield of cassava waste from harvesting and production site is about $50 \%$ of the total plant. They are usually burnt or discarded without any future pre-treatment (Idris et al., 2020). From previous studies, agro-industrial wastes such as the peel and leaf of the plant can be utilized as animal feed based on their nutritional composition (Dele et al., 2013; Kiendrébéogo et al., 2019). For example, the leaf contains 10 times more protein than the tuber, while the peel is low in protein (1-2\%) and contains high anti-nutrition (cyanide), whereas other parts of the plant are yet to determine their compositions (Siti Sarah \& Aishah, 2016, Idris et al. (2020). Additionally, the tuber constitutes major carbohydrate content that can provide a valuable supplement to the predominantly starchy diets and feed (Morgan \& Choct, 2016).

Currently, ruminants such as goat and cow diet consist of mostly grass and concentrate mixtures. However, according to a study by Tien Dung et al. (2005), a diet comprised of guinea grass has poorer nutritional value than cassava hay as cassava hay contains more crude protein, ash and fibre. Thus, cassava leaf is holds the potential to replace guinea grass as a ruminant feed. Therefore, it is crucial to determine the nutrient composition in each part of the cassava. The objective of this paper is to determine the proximate composition of all parts i.e. leaf, petiole, young stem, tuber, rind (cortex) and skin (periderm) of the white cassava plant (Rayong 90). The findings of this study would be useful to select the best parts from the cassava plant as a potential animal feed focusing on ruminants.

\section{Materials and Methods}

\subsection{Preparation of Plant Materials for Proximate Analysis}

The harvested peat cassava plants from Rayong 90 (white cassava) variety were collected randomly from the plantation located in Banting, Selangor. The plants were separated into their respective parts to include leaf, petiole, young stem, peel (cortex and periderm) and tuber as shown in Figure 1. After separation, the parts of the plant were further washed, chopped into thin slices and dried using an oven (OF-G22W, Jeio Tech, Korea) at $60^{\circ} \mathrm{C}$ for $24 \mathrm{~h}$ to preserve their nutritional content (Zainuddin et al., 2014). All samples were then grounded and sieved into fine powder at 1-mm particle size using a Mill 
Grinder (Retsch, SM200 Rostfrei, Germany) as shown in Figure 1. The ground samples were then subjected to the determination of moisture content $(\mathrm{MC})$, crude protein $(\mathrm{CP})$, crude fat (CF), crude fibre, ash and carbohydrate using methods of AOAC (1990) in triplicate.

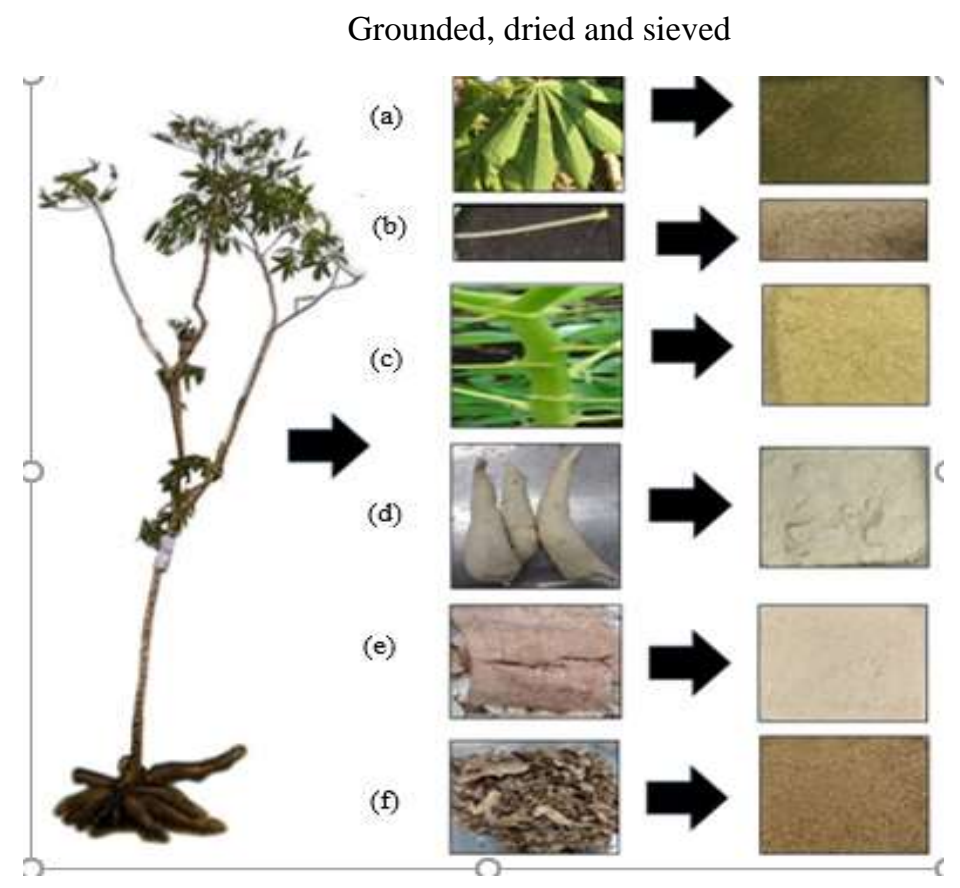

Figure 1. A simplified diagram of sample preparation for proximate analysis: (a) leaf, (b) petiole, (c) young stem, (d) tuber, (e) cortex and (f) periderm.

\subsection{Determination of $M C$}

The MC of the samples was determined using the gravimetric method (AOAC, 1990). About $5.0 \mathrm{~g}$ of each sample was placed in a crucible, weighed and dried in an oven (Memmert Incubator Oven model INB 200, Akribis Scientific Limited, Great Britain) at $105{ }^{\circ} \mathrm{C}$ for 24 $\mathrm{h}$. Then, the samples were cooled in a desiccator and weighed. The process was repeated at an hourly interval until a constant weight was obtained. The percentage of MC was calculated by equation (1):

$$
\text { MC }(\%)=\frac{(w t . o f \text { initial sample }- \text { final sample })}{w t . o f \text { initial sample }} \times 100 \%
$$

\subsection{Determination of $C P$}

CP was determined using Kjeldahl method in a Nitrogen Analyser (Model Kjeltec 2300, Foss Tecator, Denmark) (AOAC, 1990). The method was as described in the manual Foss Analytical AB manual 16. About $1.0 \mathrm{~g}$ of sample, two tablets of kjeltabs as an anti- 
bumps and $12 \mathrm{~mL}$ concentrated $\mathrm{H}_{2} \mathrm{SO}_{4}$ were poured into a $250 \mathrm{~mL}$ digestion tubes. Then, the digestion tubes were put into a rack and were loaded into a $420^{\circ} \mathrm{C}$ digestion block. All samples were digested until the solution was clear. Next, the rack of tubes was allowed to cool for 30 min prior to analysis using the Kjeltec 2300 distillation unit. The cooled, diluted samples were then further digested with $80 \mathrm{~mL} \mathrm{H} \mathrm{H}_{2} \mathrm{O}$ and $50 \mathrm{~mL}$ of $40 \% \mathrm{NaOH}$. After that, the distillation process took place until the solution changed its colour from purple to greenish-yellow. Next, the distillate was titrated with $0.1 \mathrm{~N} \mathrm{HCl}$ to a colourless endpoint. The percentage of $\mathrm{CP}$ was calculated using a conversion factor of 6.25 multiplied by the total of the nitrogen in each sample as shown in equation (2):

$$
\% \text { of } C P=\% \quad N \times 6.25
$$

\subsection{Determination of $C F$}

Determination of CF was done by direct solvent extraction method using Soxtec TM 2050, (Foss Analytical, Denmark) (Pearson, 1976). About $5.0 \mathrm{~g}$ of samples were placed in the cellulose thimbles and the top of the thimbles plugged using defatted cotton. Then, the extraction cups containing hexane were boiled for $20 \mathrm{~min}$, followed by rinsing for $40 \mathrm{~min}$ and recovering for $10 \mathrm{~min}$. Next, the cups were put in $103{ }^{\circ} \mathrm{C}$ oven for $30 \mathrm{~min}$ to remove moisture. The cups were cooled in a desiccator and weighed. The calculation for $\mathrm{CF}$ percentage is shown in equation (3):

$$
\text { CF }(\%)=(w t . o f \text { cup }+ \text { fat residue }) /(w t \text { of test sample }) \times 100
$$

\subsection{Determination of Crude Fibre}

Crude fibre content was determined by acid and alkali digestion method by using Fibertec TM (Foss Analytical; Denmark) (AOAC, 1990). About $1.0 \mathrm{~g}$ of samples and Celite 545 diatomaceous earth (Sigma Aldrich, Germany) as filtering agent were boiled in $200 \mathrm{~mL}$ of $0.25 \mathrm{~N} \mathrm{H}_{2} \mathrm{SO}_{4}$ for 30 min. Roughly 2-3 drops of 1-octanol were added to prevent foaming during boiling. Thereafter, the samples were washed with hot water four times. Then, 200 $\mathrm{mL}$ of $0.313 \mathrm{~N} \mathrm{NaOH}$ was added and boiled for another $30 \mathrm{~min}$. The hydrolysed samples were again filtered and the residue was rinsed with hot water to remove the acid. The residue was rinsed again with hot water and acetone. Subsequently, the residue in the crucible was transferred into an oven (Memmert Incubator Oven model INB 200, Akribis Scientific Limited, Great Britain) to dry at $105{ }^{\circ} \mathrm{C}$ until a constant weight was obtained. Then, the residue was ashed at $550{ }^{\circ} \mathrm{C}$ for $12 \mathrm{~h}$. Finally, the crucibles were cooled down in a desiccator and weighed. Theoretically, the weight fraction loss during ashing is the weight of crude fibre content. The percentage of the crude fibre was calculated based on the following equation (4): 
Crude fibre $(\%)=\frac{(w t . \quad \text { of crucible }+ \text { dried residue })-(w t . o f \text { crucible }+ \text { ash })}{w \text { t.of initial sample used }} \times 100$

\subsection{Determination of Ash}

Ash was estimated after moisture content procedure, where all organic constituents were burned at $600{ }^{\circ} \mathrm{C}$ using a Carbolite Ashing Laboratory Chamber Furnace (model BWF $11 / 131100^{\circ} \mathrm{C}$, USA). Then, the samples were cooled down in a desiccator and weighed. The ash percentage was calculated based on the following equation (5):

$$
\% \text { Ash }=\frac{\text { wt.of ash }}{w t . \quad \text { of dried sample used }} \times 100
$$

\subsection{Determination of Carbohydrate}

Total carbohydrate content was calculated by subtracting the sum of percentage of all other proximate parts. The equation (6) is shown below:

$$
\begin{aligned}
& \text { Carbohydrate } \\
& =100-(\% \text { moisture }+\% \text { crude protein }+\% \text { crude fat } \\
& +\% a s h+\% \text { crude fiber })
\end{aligned}
$$

\subsection{Statistical Analysis}

The values obtained from proximate analysis were expressed as mean with a standard deviation from triplicate determinations. Data were analysed by analysis of variance (ANOVA) followed by Tukey's multiple comparison test using Minitab 16.0 (State College, PA) to separate the differences in the mean values at a significance $p<0.05$.

\section{Results and Discussions}

Table 1 shows the proximate composition (moisture content, crude protein, crude fat, crude fibre, ash, carbohydrate) of the different white cassava plant parts (leaf, petiole, young stem, tuber, cortex, and periderm). Results showed that the MC of leaf, petiole, young stem, tuber, cortex, and periderm was 6.11\%, 4.63\%, 5.03\%, 3.54\%, 5.00\% and 6.66\%, respectively. The $\mathrm{MC}$ ranged from the minimum amount in periderm to a maximum amount in the young stem. This study is also in agreement with the values obtained in the analysis of cassava tuber reported by Sarkiyayi and Agar (2010), leaf done by Siti Sarah and Aishah (2016) and other cassava parts by Idris et al. (2020). However, according to Otache et al. (2017), their cortex (peel) contained higher MC as compared to the results obtained. All parts had low moisture content $(<10 \%)$ indicating good storage life. 
The CP content was found to be diverse in each part; leaf (23.87\%), petiole $(6.31 \%)$, young stem $(10.20 \%)$, tuber $(2.54 \%)$, cortex $(10.21 \%)$ and periderm $(6.68 \%)$. The CP ranged from the lowest value in flesh to the highest value in leaf. There was a significant difference between the leaf and other parts. Reportedly, leaves contain $12 \%$ of calorific value from $\mathrm{CP}$, thus can be considered as a good source of amino acids for human food and ruminant animal feed (Priya \& Chavan, 2015). This finding agrees with those reported by Fasuyi (2005), Tien Dung et al. (2005), Wanapat (2008) and Siti Sarah and Aishah (2016). According to Idris et al. (2020), the CP of most cassava leaf and hay ranged between 20-37\%. Cassava tuber had the lowest CP content (2.54\%) due to its dominant starch content followed by petiole and periderm. Tubers have been widely used in ruminant feed in the form of chips and pallets as energy sources and dried cassava leaf hay as protein (Wanapat, 2008).

Table 1. Proximate composition (\%) in different parts of the cassava plant

\begin{tabular}{lcccccc}
\hline $\begin{array}{l}\text { Proximate } \\
\text { composition }\end{array}$ & $\begin{array}{c}\text { Leaf } \\
(\%)\end{array}$ & $\begin{array}{c}\text { Petiole } \\
(\%)\end{array}$ & $\begin{array}{c}\text { Young stem } \\
(\%)\end{array}$ & $\begin{array}{c}\text { Tuber } \\
(\%)\end{array}$ & $\begin{array}{c}\text { Cortex } \\
(\%)\end{array}$ & $\begin{array}{c}\text { Periderm } \\
(\%)\end{array}$ \\
\hline MC & $5.00 \pm 0.37^{\mathrm{b}}$ & $6.11 \pm 0.1^{\mathrm{a}}$ & $6.66 \pm 0.21^{\mathrm{a}}$ & $4.63 \pm 0.72^{\mathrm{b}, \mathrm{c}}$ & $5.03 \pm 0.30^{\mathrm{b}}$ & $3.54 \pm 0.52^{\mathrm{c}}$ \\
CP & $23.87 \pm 0.67^{\mathrm{a}}$ & $6.31 \pm 0.01^{\mathrm{c}}$ & $10.20 \pm 0.60^{\mathrm{b}}$ & $2.54 \pm 0.01^{\mathrm{d}}$ & $10.21 \pm 0.01^{\mathrm{b}}$ & $6.68 \pm 0.03^{\mathrm{c}}$ \\
CF & $6.00 \pm 0.05^{\mathrm{a}}$ & $0.99 \pm 0.02^{\mathrm{c}}$ & $-0.12 \pm 0.17^{\mathrm{e}}$ & $0.53 \pm 0.10^{\mathrm{d}}$ & $0.75 \pm 0.03^{\mathrm{c}, \mathrm{d}}$ & $2.36 \pm 0.18^{\mathrm{b}}$ \\
Crude fibre & $13.66 \pm 2.01^{\mathrm{d}}$ & $42.35 \pm 0.49^{\mathrm{b}}$ & $48.00 \pm 0.97^{\mathrm{a}}$ & $2.98 \pm 0.06^{\mathrm{e}}$ & $16.42 \pm 0.08^{\mathrm{d}}$ & $33.26 \pm 2.13^{\mathrm{c}}$ \\
& & & & & & \\
Ash & $6.53 \pm 0.25^{\mathrm{b}}$ & $5.32 \pm 0.35^{\mathrm{b}, \mathrm{c}}$ & $4.53 \pm 0.7^{\mathrm{c}}$ & $2.00 \pm 0.16^{\mathrm{d}}$ & $5.35 \pm 0.43^{\mathrm{b}, \mathrm{c}}$ & $15.80 \pm 1.32^{\mathrm{a}}$ \\
& & & & & & \\
Carbohydrate & $43.80 \pm 5.91^{\mathrm{a}}$ & $38.53 \pm 0.64^{\mathrm{b}, \mathrm{c}}$ & $30.48 \pm 1.63^{\mathrm{c}}$ & $86.77 \pm 0.44^{\mathrm{b}}$ & $61.90 \pm 0.49^{\mathrm{a}}$ & $38.35 \pm 2.62^{\mathrm{b}, \mathrm{c}}$ \\
\hline
\end{tabular}

Mean values having different superscript in a row are significantly different at $p<0.05$

$\mathrm{CF}$ is essential for the structure and biological functions to provide higher energy value compared to other nutrients (Eleazu \& Eleazu, 2012). Results showed that the CF in leaf, petiole, young stem, tuber, cortex and periderm was $6.00 \%, 0.99 \%,-0.12 \%, 0.53 \%$, $0.75 \%$ and $2.36 \%$, respectively. Cassava leaf had the highest crude fat content $(6.00 \%)$ and significantly $(p<0.05)$ different compared to the other cassava parts. The results of this study agree with the findings by Wanapat (2008), Siti Sarah and Aishah (2016) and Idris et al. (2020). The differences in CF could be affected by its gross energy as the leaf contained the highest gross energy content (Idris et al., 2020).

Crude fibre is a portion of carbohydrate which is non-digestible by the body and consists mainly of cellulose, lignin and other soluble fibres (Idris et al., 2020). The crude fibre of the leaf, petiole, young stem, tuber, cortex and periderm was $13.66 \%, 42.35 \%$, 
$48.00 \%, 2.98 \%, 16.42 \%$ and $33.26 \%$, respectively. The findings indicated that the highest crude fibre content was observed in young stem. The crude fibre values recorded in this study are consistent with those reported by Siti Sarah and Aishah (2016) for cassava leaf and Idris et al. (2020) for other cassava plant parts. According to the research done by Nordfeldt et al., (1950), when measured based on dry matter content of the ration, the crude fibre amount in the feed should not exceed $16.00 \%$ of the feed.

All parts except tuber showed high ash content $(>3.00 \%)$ that reflected on the mineral content preserved in the samples. The periderm was different significantly $(p<0.05)$ from other cassava parts with higher values followed by leaf (6.53\%), petiole (5.32\%), cortex $(5.35 \%)$, young stem $(4.53 \%)$ and tuber $(2.00 \%)$. The data is within the range of other studies done by Siti Sarah and Aishah (2016) for leaf and Idris et al. (2020) for other cassava plant parts. The high values of ash in cassava peel could be useful in animal feed formulation according to Otache et al. (2017).

Meanwhile, the carbohydrate content of the leaf, petiole, young stem, tuber, cortex and periderm was $43.80 \%, 38.53 \%, 30.48 \%, 86.77 \%, 61.90 \%$ and $38.35 \%$, respectively. Carbohydrate content ranged from $30.53 \%$ (young stem) to $86.77 \%$, with tubers having the highest carbohydrate content. Thus, the tuber can be prepared as dietary energy carbohydratebased food due to its major component of starch.

\section{Conclusions}

The results of this study showed that the leaf of white cassava (Rayong 90 variety) would be suitable to be addressed as protein-energy ruminant feed due to its high content of crude protein $(23.87 \%)$ which was three times higher than the average of the other cassava parts. Even though it had lower carbohydrate content $(43.80 \%)$ than tuber $(86.77 \%)$ and cortex $(61.90 \%)$, it was still $22 \%$ higher than petiole, young stem and periderm. From the proximate analysis, it can be concluded that the leaf is the best cassava part for ruminant feed. It is recommended that clinical studies should be conducted to investigate its toxicity and side effects on the ruminant.

Acknowledgments: The authors would like to express their gratitude to the Universiti Putra Malaysia for providing financial and technical support to conduct this research.

Conflicts of Interest: The authors declare no conflict of interest, and also the funders had no role in the design of the study; in the collection, analyses, or interpretation of data; in the writing of the manuscript, or in the decision to publish the results.

\section{References}

Alves, A.A.C. (2002). Cassava botany and physiology. In: Hillocks, R.J., Thresh, J.M., \& Bellotti, A. (Eds). Cassava: Biology, Production and Utilization, pp. 67-89. UK: CABI. 
AOAC. (1990). Association of Official Analytical Chemist. Official methods of analysis. Washington, DC.

Boonseng, O., Santisopasri, V. S., Soommart, A. (1999). Effect of planting seasons, varieties and harvesting times on biochemical properties of cassava (Manihot esculenta Crantz) Roots. Kasetsart Journal of Natural Science, 33, 497-506.

CIAT. (2009). Key access and utilization descriptors for cassava genetic resources. Bioversity International, Rome, Italy, International Centre for Tropical Agriculture (CIAT). Cali, Colombia.

Dele, P., Jolaosho, A., Arigbede, O., et al. (2013). Chemical composition and in vitro gas production of silage from guinea grass, cassava peel and cashew apple waste at different periods of ensilage. Pakistan Journal of Biological Sciences, 16(23), 1801-1805.

Department of Agriculture Malaysia. (2018). Vegetables and cash crops statistic Malaysia.

Eleazu, C. \& Eleazu, K. (2012). Determination of the proximate composition, total carotenoid, reducing sugars and residual cyanide levels of flours of 6 new yellow and white cassava (Manihot esculenta, Crantz) varieties. American Journal of Food Technology, 7(10), 642-649.

Fasuyi, A. O. (2005). Nutrient composition and processing effects on cassava leaf (Manihot esculenta, Crantz) antinutrients. Pakistan Journal of Nutrition, 4(1), 37-42.

Foss Analytical A. B. (2003). Manual for Kjeltec System 2300 Distilling and Titration Unit.

Idris, S., Shamsudin, R., Nor, M., et al. (2020). Physicochemical composition of different parts of cassava (Manihot esculenta Crantz) plant. Food Research, 4(S1), 78-84.

Kiendrébéogo, T., Zampaligré, N., Ouédraoogo, S., et al. (2019). Cassava by-products as feed for pigs in Burkina Faso: Production processes, nutritive values and economic costs. Open Access Library Journal, 6(9), 1-14.

Morgan, N. K., \& Choct, M. (2016). Cassava: Nutrient composition and nutritive value in poultry diets. Animal Nutrition, 2(4), 253-261.

Nordfeldt, S., Iwanaga, I., Morita, K., et al. (1950). Influence of crude fiber in the ration on the efficiency of feed utilization by dairy cows. Journal of Dairy Science, 33(7), 473-485.

Okudoh, V., Trois, C., Workneh, T., et al. (2014). The potential of cassava biomass and applicable technologies for sustainable biogas production in South Africa: A review. Renewable and Sustainable Energy Reviews, $39,1035-1052$.

Otache, M., Ubwa, S., \& Godwin, A. (2017). Proximate analysis and mineral composition of peels of three sweet cassava cultivars. Asian Journal of Physical and Chemical Sciences, 3(4), 1-10.

Pearson, D. (1976). General Methods in the Chemical Analysis of Foods, Longman Group, London.Priya, D. P., \& Chavan, N. S. (2015). A comparative study of nutrients and mineral composition of Caralliabrachiata (Lour.) Merill. International Journal of Advances in Scientific Research, 1, 90-92.

Sarkiyayi S., \& Agar, T. M. (2010). Comparative analysis of the nutritional and anti-nutritional contents of the sweet and bitter cassava varieties. Advance Journal of Food Science and Technology, 2(6), 328-334. 
Siti Sarah, J., \& Aishah, B. (2016). Nutrient and antinutrient composition of different variety of cassava (Manihot Esculenta Crantz) leaves. Jurnal Teknologi , 78(6-6), 59-63.

Tien Dung, N., Thi Mui, N. \& Ledin, I. (2005). Effect of replacing a commercial concentrate with cassava hay (Manihot esculenta Crantz) on the performance of growing goats. Animal Feed Science and Technology, $119(3-4), 271-228$.

Wanapat, M. (2008). Potential uses of local feed resources for ruminants. Tropical Animal Health and Production, 41(7), 1035-1049.

Zainuddin, M. F., Shamsudin, R., Mokhtar, M. N., et al. (2014). Physicochemical properties of pineapple plant waste fibers from the leaves and stems of different varieties. BioResource, 3(9), 5311-5324.

Copyright (C) 2021 by Idris, S. et al. and HH Publisher. This work is licensed under the Creative Commons

Attribution-NonCommercial 4.0 International Lisence (CC-BY-NC4.0) 